\title{
Colorectal Neuroendocrine Tumor pT1b TNM Finding v8
}

National Cancer Institute

\section{Source}

National Cancer Institute. Colorectal Neuroendocrine Tumor pT 1b TNM Finding v8. NCI Thesaurus. Code C135188.

Colorectal neuroendocrine tumor measuring $1-2 \mathrm{~cm}$ in greatest dimension. (from AJCC 8th Ed.) 